Preparing practitioners to conduct educational research and evaluation: What the research says and what our experiences taught us

By: Katherine Cumings Mansfield and Jaime Stacy

Mansfield, K.C. \& Stacy, J. (2017). Preparing practitioners to conduct educational research and evaluation: What the research says and what our experiences taught us. Journal of Research on Leadership Education, 12(3), 302-334. https://doi.org/10.1177/1942775116668524

***(C) 2016 The University Council for Educational Administration. Reprinted with permission. No further reproduction is authorized without written permission from SAGE. Reuse is restricted to non-commercial and no derivative uses. This version of the document is not the version of record. ***

\begin{abstract}
:
The purpose of this article is to share the insights gleaned from the literature and our on-theground realities teaching practitioners to conduct educational research and evaluation. We focus on four areas we have found most important for teaching practitioner-scholars: (a) giving careful attention to andragogy versus pedagogy, (b) engaging the potency that team teaching affords, (c) addressing challenges associated with the practitioner-scholar model, and (d) building on the strengths of the cohort model. We share the challenges and possibilities of each strategy and close by offering recommendations for the educational leadership field in moving forward.
\end{abstract}

Keywords: leadership preparation programs | andragogy | pedagogy | cohort model | team teaching | doctoral programs | scholar-practitioner | practitioner-scholar

\title{
Article:
}

Most schools of education use a traditional scholar-model that prepares students to join the ranks of the professoriate. However, there is a distinct and emerging field that focuses on developing practitioners to solve real-world problems (Amrein-Beardsley et al., 2012; Auerbach, 2011; Barnett \& Muth, 2008). In considering the structure of programs designed to graduate practitioner-scholars, especially those with an emphasis placed on leadership development, relatively little research on the topic currently exists. Limited research on the topic, paired with an increasing consumer demand for degree programs that are hands on, relevant, and meaningful, point to the need for additional research in this area.

Preparing practitioners to conduct education research and evaluation holds potential for leveraging change, among other positive returns. However, in addition to assets, there are specific challenges involved, as well. The purpose of this article is to describe one university's unique approach to offering doctoral studies for practitioners. In addition, we share insights that emerged from reflecting on the literature along with our experiences teaching practitioners how to conduct educational research and evaluation. In doing so, we aim to not only strengthen our program and practice but also contribute to the meaning making of fellow colleagues as they 
design new, or revise existing, preparation programs that center on the practitioner-scholar approach.

We describe some of the challenges we experienced and particular strategies we implemented that might be adapted to colleagues' specific programs. We begin with sharing understandings we gleaned from the literature. We then explain how we approached the course, giving background information about our students and university, an overview of the EdD program, and an explanation of the year-long evaluation course we developed and taught. We then share a narrative analysis of the meaning making that emerged while engaging in reflective practices, focusing on four distinct themes: (a) giving careful attention to andragogy versus pedagogy, (b) engaging the potency that team teaching affords, (c) addressing challenges associated with the practitioner-scholar model, and (d) building on the strengths of the cohort model. We close the article with a discussion of lessons learned and recommendations for moving forward.

\section{What We Learned From the Literature}

Professors in management-oriented fields are beginning to respond to the demographic shifts of contemporary students by moving toward more learner-centered frameworks (Forrest \& Peterson, 2006). This seems especially true in fields that are devoted to educating working professionals in recognition of the many roles and responsibilities they bring to the learning context (Fornaciari \& Dean, 2014; Forrest \& Peterson, 2006). Moreover, there is a shift of philosophy in fields such as social work, education, and business management, that student learning should be experiential and directly connected to real-world application via activities that mirror on-the-job realities (Black \& Murtadha, 2007; Bowers \& Murakami-Ramalho, 2010; Brown, 2004; Pollio \& Macgowan, 2010). Taken together, it can be said that higher education professors and administrators need to, and are beginning to, shift their attitudes, knowledge, and skills away from pedagogy and toward andragogy to meet the demands of our changing student populations, as well as to match the push in public administration and social service professions to translate their learning to produce substantive change in their respective fields (Brown, 2004; Dean \& Fornaciari, 2014; Fornaciari \& Dean, 2014; Forrest \& Peterson, 2006). The section below unpacks these ideas in greater detail.

\section{Andragogy Versus Pedagogy}

The literature draws distinctions between pedagogy and andragogy. Forrest and Peterson (2006) use the dictionary definition: Pedagogy is the art and science of teaching children and andragogy is the art and science of teaching adults. Although some professors might argue they obviously teach adults, and what we call it does not matter, others would argue many professors actually teach as if they were working with children, rather than adults (Fornaciari \& Dean, 2014; Forrest \& Peterson, 2006).

For example, andragogy involves a purposeful power-sharing between professor and student (Dean \& Fornaciari, 2014; Fornaciari \& Dean, 2014; Forrest \& Peterson, 2006; Pollio \& Macgowan, 2010) and a movement from "subject-centered pedagogy to learner-centered andragogy" (Forrest \& Peterson, 2006, p. 115). According to Fornaciari and Dean (2014), this means the role of the instructor must move from center stage to sidelines and active teaching and 
learning processes replace emphases on content. In pedagogy, teachers are the experts; whereas, in andragogy, students' knowledge and prior experiences interact with course content and professors' expertise (Forrest \& Peterson, 2006). Moreover, according to Forrest and Peterson (2006), an adult is anyone who has taken on adult roles in society, whether they are a teenager or octogenarian:

An adult is someone who has assumed the primary social role of worker, spouse, or parent ... They have assumed primary responsibility for their own lives. (p. 114). . Unlike children, adult learners are not defined by their roles as students but rather by the various identities they must use to live their lives (p. 116). . . as adults voluntarily choose to enter the educational world, they do not leave these other identities behind. (p. 117)

Power-sharing, student-centered, and experiential contrasts sharply with most conceptions of the so-called Ivory Tower where the professor is a super star expert who lectures while students' heads, like empty containers, passively wait to be filled with the divo/a's knowledge. But, how do we shift from a professor-centered pedagogy to an adult student-centered andragogy? Where do we begin?

Forrest and Peterson (2006) contend we must start with the language we use, arguing that pedagogy is an archaic term that may reify the notion that college students are dependent children rather than independent adults. We must let our vocabulary evolve with our changing perspectives and approaches. For example, there is no doubt that Black and Murtadha (2007), Bowers and Murakami-Ramalho (2010), and Brown (2004) are actually referring to andragogical strategies when they describe their signature pedagogies. Their push for leadership preparation programs to be more focused on collaborative research and communities of learning, where critical thinking, authentic learning, and real-world application are key, aptly describes a context in which professors power with, rather than power over, and where adult students' prior learning and experiences become an integral part of the developmental learning process. The notion is that by using the term andragogy, rather than pedagogy, we may attract people's attention, signal to the profession that we are describing transformative change, and help us move forward.

In addition to updating the language we use, it is important to be aware of and communicate the assumptions of the andragogical framework. That is, adult learners

1. are self-directed, self-motivated, and come to the learning process ready to learn (Brown, 2004; Centre for the Enhancement of Learning and Teaching [CELT], 1998; Fornaciari \& Dean, 2014; Forrest \& Peterson, 2006);

2. bring a wealth of experience to the learning process (Forrest \& Peterson, 2006; Hanusch, Obijiofor, \& Volcic, 2009; Pollio \& Macgowan, 2010);

3. are oriented toward experiential and problem-based learning and active application of theory to practice (Black \& Murtadha, 2007; Bowers \& Murakami-Ramalho, 2010; Brown, 2004; CELT, 1998; Eisen \& Tisdell, 2003-2004; Fornaciari \& Dean, 2014; Forrest \& Peterson, 2006; Pollio \& Macgowan, 2010); 
4. need to know the reason for learning something and prefer learning that which is relevant to their lives (Dean \& Fornaciari, 2014; Fornaciari \& Dean, 2014; Forrest \& Peterson, 2006; Hanusch et al., 2009);

5. must be engaged in critical reflection (Black \& Murtadha, 2007; Bowers \& MurakamiRamalho, 2010; Brown, 2004; Eisen \& Tisdell, 2003-2004; Hanusch et al., 2009; Pollio \& Macgowan, 2010; Vanderbilt, n.d.); and

6. need to learn how to work collaboratively (Black \& Murtadha, 2007; Bowers \& Murakami-Ramalho, 2010; Eisen \& Tisdell, 2003-2004; Hanusch et al., 2009; Pollio \& Macgowan, 2010; Vanderbilt, n.d.).

However, Brown (2004) cautions that integrating the above assumptions into philosophy and practice is not necessarily threat-free as they challenge established norms. Moreover, some students are unprepared to collaborate with classmates and community members and thus may experience unexpected stress and/or resist changing expectations and/or disengage (Fornaciari \& Dean, 2014). Nonetheless, regardless of the risks, taking an andragogical approach is not only more appropriate for adult learners, but it also potentially leads to a richer educational experience (Brown, 2004; Eisen \& Tisdell, 2003-2004).

Why is andragogy so important? Whitby (2015) made an incredibly astute observation when he pointed out many educators of children, who are "so skilled in a classroom of kids, [are] so bad at teaching in a room full of adults" (n.p.). As explained earlier, adults are essentially driven by different motivators than children are, and educators of children are not always in tune with those motivators. Whitby (2015) also questioned why adult learning spaces seem to be driven solely by a PowerPoint presentation. Whitby also wondered whether the set of slides is truly relevant or engaging, or whether the adult learners are just skilled at appearing compliant while they check email or preferred social media instead.

Today's audiences crave engagement, preferably on some sort of social platform, which encourages interaction among peers. Teachers are seen as a type of performer, and some form of high-quality entertainment is expected. Of course, entertaining adults is far different from entertaining children, which is why the most popular children's movies contain certain lines which appeal to an adult audience while drawing in the child. Adults possess an appreciation for the subliminal nuances between the lines of the script. Tastes are more sophisticated, more discriminating.

At one time, the only studies which existed on the concept of adult learning were centered around the question as to whether or not adults were still capable of learning. Merriem (2001) points out that the concept of adult education is relatively new, as it has only been considered a "professional field of practice" (p. 3) since 1926. Merriem continues by reflecting upon early assessment strategies used to determine adult learning capacities and found they were actually rather biased in that assessment tools were timed and based on concepts learned through traditional schooling rather than real-life experience. Teaching content from an andragogical lens is, in short, providing instruction based on the needs of the adult learner by applying the abovereferenced framework to a curriculum rich in evidence-based instructional strategies that include experiential learning, collaboration among class participants, and team teaching, to be discussed next. 
Team Teaching

As stated above, team teaching is an additional strategy that is more suited to adult learners. But there is more. Some professors and researchers believe that team teaching leads to deeper learning. For example, according to Eisen and Tisdell (2003-2004),

More than ever, those of us who teach in higher education are expected to help learners develop their critical thinking skills. Our job is ultimately to enable students to integrate new information from a variety of disciplines so they can become ongoing constructors of new knowledge, both on an individual level and with others in a social context. It is our belief that team teaching is an overlooked "low tech" alternative for facilitating the kind of learning that develops skills in critical thinking and new knowledge construction. Our unabashed advocacy of teaming is rooted in our experience. (emphasis added)

However, adds Eisen and Tisdell, team teaching should be viewed as an alternative rather than a universal solution. That is, colleagues should consider both the benefits and the challenges to determine whether team teaching is right for them and for their particular programs. Thankfully, in addition to pros and cons, researchers also offer numerous recommendations to ease the transition from traditional solo work to collaborative teaching, which are explained below.

Benefits. There are many advantages to team teaching, especially, because doing so supports using an andragogical framework. However, to harness and advance the potency that team teaching affords, partners must first possess and express basic compatibility and mutual respect, practice honesty, have a genuine interest and concern for the learning process, be open-minded, and be willing to explore and experiment (Hanusch et al., 2009; Vanderbilt, n.d.). After these basics are in place, team teaching has the potential to model for students the negotiation of relationships and power (Eisen \& Tisdell, 2003-2004), the development of working collaborations (Hanusch et al., 2009), collegial debate (CELT, 1998; Stanford University, 2007), and the free exchange of intellectual ideas (Hanusch et al., 2009). Moreover, researchers have found team teaching is more conducive to dynamic and interactive learning environments (CELT, 1998; Stanford University, 2007) and facilitates power with rather than power over (Eisen \& Tisdell, 2003-2004; Vanderbilt, n.d.).

In addition, team teaching also promotes using a dialogic structure versus lecture format (Stanford University, 2007) and, hence, transforms learning by changing students from passive recipients of information conveyed by the expert to "active agents in the construction of knowledge" (Eisen \& Tisdell, 2003-2004), making deep learning and critical thinking not only possible, but more probable (Eisen \& Tisdell, 2003-2004; Hanusch et al., 2009; Vanderbilt, n.d.). Using a dialogic structure supports and compels interaction between and among teachers and students (Stanford University, 2007). In addition, dialogic approaches are more conducive to collaborative learning (Eisen \& Tisdell, 2003-2004) and improved student performance, especially in terms of growing independence and assuming responsibility for learning (CELT, 1998). The team teaching approach also has potential to strengthen grading practices as students 
receive augmented feedback from an instructional team rather than a single instructor (Stanford University, 2007).

Challenges. In addition to benefits, researchers report a few important challenges involved with implementing team teaching: the additional complexity (CELT, 1998) and increase in preparation time (Stanford University, 2007). If the team is not well-organized, connected, and communicative, difficulties will surely arise (Vanderbilt, n.d.). The lack of cohesion and agreement among team members could result in student confusion (Hanusch et al., 2009; Vanderbilt, n.d.) and waylay potential benefits.

Finally, there is always the chance that students will resist taking a more active role in their learning process. Many students are accustomed to the lecture format and are used to sitting idly while one professor does all the talking. As a result, faculty will have to work hard to overcome student resistance to dialog and active participation (Stanford University, 2007).

Tips for success. Researchers offer many suggestions for those considering implementing team teaching. The list below, while taken from varied sources, is not meant to be exhaustive:

1. Keep teaching teams small. It is easier to control the level of continuity and cohesiveness. (Hanusch et al., 2009)

2. Team members should agree to contribute equally and/or agree on roles and responsibilities if one person is the "lead." (CELT, 1998)

3. Team members should expect to work together on careful and extensive planning. (Stanford University, 2007)

4. Make sure team meetings are productive! (CELT, 1998)

5. Team members should strive to reach consensus. (Stanford University, 2007)

6. Team members should discuss how conflict will be handled. (CELT, 1998)

7. Be present and active even when you are not the teacher in the lead at the moment. Sit with the students and model exemplary student behavior by asking questions and offering commentary. (Stanford University, 2007)

8. Refer to each other's ideas. Model synthesis and integration. Interweave partner's perspectives into your talk. (Stanford University, 2007)

9. Agree on standards. Design rubrics together. Strive for collaborative grading. (Stanford University, 2007)

10. Make continuous assessment very "real life" and give lots of feedback. (Hanusch et al., 2009)

11. Monitor how students are reacting to the team teaching/collaborative learning experiences. (CELT, 1998)

12. Co-author a paper that was inspired by team teaching a course. (Stanford University, 2007)

Finally, according to Hanusch et al. (2009), the vast majority of research on teaching and learning at the tertiary level suggests that team teaching is beneficial to both students and faculty (e.g., decreased isolation and increased collegiality). Stanford University (2007) agrees, "Ultimately, the advantages of team teaching far outweigh the time and energy it requires" (p. 4). Moreover, proof that team teaching works is revealed in student evaluations (CELT, 1998). 


\section{The Practitioner-Scholar Model}

In addition to team teaching and taking a more andragogical approach, additional trends are emerging that further distinguish between the needs of adult learners who have varied career and educational aspirations. For the educational leadership field, it is important to consider differences between the traditional $\mathrm{PhD}$ program and programs that train practitioners to use research to solve real-world problems. The literature refers to these new foci as the practitionerscholar model (or scholar-practitioner model). Prior to this, practitioners have been seen as those who engage in their work on a daily basis, hoping to learn and grow from experience, while scholars were the theorists - learning while conducting extensive research on their chosen topics. In recognition of this issue, many higher education institutions have launched doctoral programs designed to graduate practitioner-scholars: individuals who wish to possess a scholarly skillset while also continuing to serve as a practitioner within an organization. These programs aim to "produce knowledge with a potent combination of rigor, relevance, and accessibility" (Salipante \& Aram, 2003, p. 130).

Why should practitioners know how to conduct research? Those who serve within a leadership role often possess or, at the very least, share the responsibility of moving the organization of which they are part toward a common goal. Within most systemic structures, decision making has not only become data-driven, it has also become evidence-based. A need exists within these structures for individuals who are able to operate "reflexively in the boundaries between theory and practice" (Bailey, 2014, p. 47).

Challenges of educating practitioner-scholars. One of the greatest challenges educating a practitioner-scholar is determining what they need to know to be successful in their chosen career. Hebert (2010) points out a practitioner-scholar "must be a craftsman of his or her trade, wisely selecting appropriate tools that will serve to accomplish the specific task" (p. 34). One must also take into account the profile of the average student enrolled in the program has changed as well. No longer is it a program designed specifically for the K-12 practitioner.

\section{The Cohort Model}

One of the strategies used to meet the needs of the scholar-practitioner is the cohort model. However, even the strongest proponents of the cohort model are aware of the drawbacks of a group of individuals moving through a set curriculum at the same time. Challenges with cohortbased degree programs have included personality conflicts among cohort members, a more confined expansion of knowledge, and students' lack of access to usable coursework that may not be a part of the prescribed curriculum (Bista \& Cox, 2014).

Personality conflicts. Strong cohorts are comprised of people from diverse backgrounds, skillsets, and experiences (Pemberton \& Akkary, 2010). Because of this, personality conflicts are to be expected. This may be due in part to an employment environment that emphasizes competition rather than collaboration (Seed, 2008). Thus, personality conflicts can hinder productivity in cohorts (Barnett, Basom, Yerkes, \& Norris, 2000; Bista \& Cox, 2014). Bista and 
Cox (2014) also suggest hostility among some cohorts is so strong that behaviors exhibited are more "like the members of a dysfunctional family" (p. 6).

Constricted knowledge base. Unlike most students seeking a $\mathrm{PhD}$, students working in a cohortbased EdD program likely know their graduation year before they even begin coursework. Cohort members work a prescribed curriculum of courses relative to the discipline in which the degree is offered. Because of the time constraint, students in cohort-based programs do not always have the opportunity to take electives courses which may strengthen their research methods. A study conducted by Walker and Haley-Mize (2012) reflects this, showing that the research methods conducted by students in an EdD program is far less varied than methods of counterparts working through a $\mathrm{PhD}$ program.

Programmatic constraints. A related concern deals with programmatic structure. For example, the program evaluation course explored in this article takes place during the second year of the cohort program. While convenient, this structure can also prevent an individual from completing the program if a personal or professional incident requires them to take time off from coursework (Barnett et al., 2000). Students cannot simply pick up where they left off, and likely need to start over at the beginning of the program or jump in with an unknown cohort when that course is offered again in the cycle.

\section{How We Approached the Course}

While we had no prior intention to formally study our teaching experiences, we were committed to reflective practice (Danielson, 2009; Ferraro, 2000; Leigh \& Bailey, 2013; Smith, 2012) from the start. That is, we have recognized reflection as a "core professional competency in the helping professions" (Leigh \& Bailey, 2013, p. 160) and have regularly incorporated reflective writing as a professional development activity (Ferraro, 2000; Smith, 2012). An article in Educational Leadership (Danielson, 2009) captures the reflective process well:

Expert teachers adjust their thinking to accommodate the level of reflection a situation calls for. Their teaching is characterized by an intentional competence that enables them to identify and replicate best practice, refine serendipitous practice, and avoid inferior practice. Because of their ability to reflect, great teachers know not only what to do, but also why.

Recognizing that some theorists define reflective practice as something that happens after an event (reflection on action), while others advocate for reflection-in-action, which occurs in real time, we have aspired to take a more holistic approach by incorporating both (Leigh \& Bailey, 2013; Smith, 2012), as "both are essential for optimal growth in the education profession" (Smith, 2012, p. 1). Indeed, as former K-12 teachers, we are well-acquainted with the need to be flexible and change our approach to a lesson mid-stream if we assess that students are not "getting it" (reflection-in-action). In addition, we have made it a "habit of mind" to consciously reflect on our practice either alone or with a trusted colleague. Thus, it was not unusual or excessively demanding for us to continue reflective practice during our team teaching experiences in an adult, higher education setting. 
In addition to acknowledging the above, it is also important to consider that if we had planned from the start to convey our lived experiences in a more formal way, we most likely would have approached our methodology more formally, as well. For example, before the first class, we may have chosen to establish written research questions ahead of time. However, recognizing the iterative nature of qualitative methods, it is likely that we would have advocated for entering the setting without specific questions in mind (Patton, 2002; Wolcott, 2008). Regardless, we did enter the process (teaching, reflecting, and reporting) with the purpose to garner knowledge to improve our practice and to share our discoveries with colleagues to start a conversation beyond ourselves in terms of identifying best practices when teaching practitioner-scholars.

Our inquiry process is similar to other qualitative approaches. For example, according to Emerson, Fretz, and Shaw (1995), participant observation and field notations are the heart of ethnographic data collection, enabling the examination of culture - in this case, the culture of our classroom. We were obviously active participants during observations, and our field notes were central to our meaning making. In addition, following Wolcott (2008), we took an active role in the inquiry process by asking questions of participants (students and each other) and examining cultural artifacts (e.g., lesson plans). As such, observing, conferencing, and taking detailed notes were important data sources in our approach to the course.

It is also important to share another aspect of our process, that is, using our philosophies on teaching in the K-12 setting to inform how we approached our inquiry method. Namely, as constructivists, who believe humans co-construct knowledge via interaction, we attest that reflective practice, as a method, helped us give language to and make meaning of what we experienced as a teaching team (Crotty, 1998; Guba \& Lincoln, 1998). After the conclusion of the class, we also used course evaluations as an additional data source to make meaning of our experiences, which we share later on in the article.

Finally, more traditional forms of inquiry rely on the criteria of objectivity and validity for evaluating trustworthiness. However, when working in a naturalistic environment such as a university classroom, trustworthiness is evaluated differently with a major criterion, the notion of credibility. That is, qualitative reporting should have an expressive quality that conveys "intense familiarity with the subjects and their ways" (Bates, 1997, p. 1167). We feel we have done the best we can to credibly capture our classroom experiences and report them ethically and responsibly.

\section{Background}

Students enrolled in Virginia Commonwealth University's EdD program have evolved from its inaugural cohort in 2008 of 18 school administrators working in the same division to a diverse set of individuals leading educational and professional development efforts within corporate America and non-profit agencies in addition to serving in leadership positions within K-12, higher education, and health administration sectors. The cohort referenced throughout this article remains the most diverse to date in terms of represented professions. Participants included the following:

1. Vice president and senior learning consultant for a nationally known bank, 
2. Five building level school administrators,

3. Two high school counselors,

4. Three individuals serving as central office personnel for K-12 school divisions,

5. An independent educational consultant,

6. A social worker and adjunct faculty of social work at a local university,

7. An assistant vice-provost for strategic enrollment management,

8. An assistant dean for curriculum within an institution's school of medicine, and

9. A faculty administrator for a higher education institution.

In addition, the future aspirations of the participants also vary. Some wish to seek a promotion within their field while others are in pursuit of a career change.

Overview of the EdD Program

Unlike the traditional $\mathrm{PhD}$ program, VCU's EdD program is designed so participants complete a 48-hr program in 36 months alongside fellow cohort members. During the first year of instruction, class sessions include activities which allow students to get to know their own strengths and weaknesses as a leader. The Learning Connections Inventory (LCI), which is affiliated with the Let Me Learn Process ${ }^{\circledR}$, as well as the Myers Briggs Assessment (MBTI) ${ }^{\circledR}$ are administered during participants' first weeks to allow opportunities for students to reflect upon the findings and apply this knowledge through team-building activities and other future coursework.

In the second year, the focus on coursework shifts from themes of theory and policy to ones which require students to investigate and solve problems through laboratories of practice. A collaborative approach remains prominent as the majority of the work is team-based. Throughout the first 2 years, an emphasis is also placed upon enhancing participants' skills as professional writers.

The capstone is the focus of the third and final year in the program and is another facet of VCU's EdD program which contributes to its uniqueness. To ensure students are provided with a rigorous and meaningful learning experience, VCU faculty reach out to area organizations such as school divisions, non-profit agencies, and higher education institutions to engage in preliminary discussions of a possible research collaboration. Interested organizations then submit a formal "Request for Assistance" (RFA) that sketches the problem of practice they would like student groups to investigate. That summer, after groups are formed, studies selected, and Chairs assigned, the Chair and student teams meet with clients to clarify the purpose of the evaluation and discuss the specific problem under investigation in greater detail. The client, Chair, and capstone teams work together to craft the research questions and discuss what collection tools might be necessary to answer those questions. The summer session is devoted to developing the evaluation proposal, which includes a formal literature review and detailed description of the proposed methods to conduct the evaluation.

Data collection takes place in the fall after the formal proposal defense. Methods vary according to the type of evaluation conducted, but often include interviews, focus groups, and surveys. Data may also include observations as well as a review of archived documents. Students aim to 
complete data collection by mid-January so preliminary analyses can begin. During the spring semester, students continue analysis and interpretation activities. Similar to a dissertation, the students focus their writing on the findings. Unlike the dissertation, the final chapter is very practitioner-focused. That is, students devote a significant amount of time and space on producing recommendations before concluding the five-chapter report.

In April or May, students present their final report and executive summary to the client. Thereafter, students present a more formal "final defense" to their capstone committee.

\section{Focus on Year 2: Teaching Practitioners to Conduct Research and Evaluation}

During the fall semester of Year 2, the cohort is enrolled in the first half of the methods course officially titled "Evidence-Informed Perspectives on Practice I." They are also enrolled in a Saturday workshop that is designed to hone their writing skills and teach them how to craft their writing products for a variety of audiences. The course description reads,

This course implements a collaborative approach to the theory-infused practice of program and policy evaluation. Participants work collaboratively to develop a study of a "problem of practice" that aligns as much as possible with their research interests and employment sites. The course culminates in the production of an Evaluation Proposal, which sets the stage for the second half of the course (Evidence-Informed Perspectives on Practice II) next semester, which focuses on implementing the study that was developed during this course. From the proposal, participants also develop an "executive summary" or "interim report" for the client.

While research and evaluation projects designed for course assignments do not require students to go through the full institutional review board (IRB) process, we do require students to complete the online training and certification in Basic Human Subjects Protection in Social and Behavioral Research through the Collaborative IRB Training Initiative (CITI). Most students in this program plan to continue their careers as practitioners and/or administrators in $\mathrm{K}-12$, higher education, or business sectors and, thus, do not have plans to publish the research from their capstones. However, during the capstone year, students are coached by faculty to successfully complete the IRB process as the project necessitates.

The first three class sessions, which meet on weekday evening from 4:30-8:30 p.m., focus primarily on the basics of research and evaluation such as conflict of interest and research ethics. Other goals include ensuring students understand essential terms and definitions as well as basic research and evaluation concepts such as merit, worth, formative evaluation, implementation evaluation, summative evaluation, utility, feasibility, propriety, accuracy, and meta-evaluation. During this time, students are also encouraged to brainstorm possible "problems of practice" that they might study this year with a partner or a team of three.

During the fourth session, we finalize what we call the "research collaboratives" in terms of team members, topic/issue, and site selection. We also conduct a large-group teaching session that discusses the purposes and components of logic models and their relationship to the first section of the evaluation proposal, especially, the description of "The Evaluand." The collaboratives 
then work together on sketching their logic models, while also outlining their purpose statement and research questions. We then assign ourselves as coaches/mentors to corresponding groups. Jaime led three groups of three $(n=9)$ and Katherine guided four groups composed of two or three $(n=11)$ " During the fourth session, we spend ample one-on-one time with each group while they are working on their logic models and drafting their purpose statements and research questions. We find this small group consulting and coaching works best to meet student needs and answer questions specific to each project.

Meanwhile, independent readings for Weeks 3 through 5 introduce students to four major paradigms for conducting research and evaluation: Postpositivist Paradigm, Pragmatic Paradigm, Constructivist Paradigm, and Transformative Paradigm (as defined in Mertens \& Wilson, 2012). On Week 5, small groups (different from research collaboratives) lead the class in a discussion of the major characteristics of their assigned paradigm and give examples of the types of evaluations that might be conducted — and the research questions that might be asked — using their particular paradigm.

The following week, we plan a brief interactive lecture that focuses on working with stakeholders. As a large group, research collaboratives share a short description of their project and explain who they believe their stakeholders are. Students are given time to ask questions and help each other determine whether particular individuals or groups are missing. Thereafter, research collaboratives work together to finalize their logic models ${ }^{1}$ and drafts of Chapter 1 of their proposal to turn into their mentors for feedback. Meanwhile, students are reading articles on their topic and developing their literature reviews as assigned as part of the all-day Saturday writing workshops.

During Weeks 7 and 8, students revise their Chapter 1 based on our feedback. They also have two opportunities to revise the literature reviews based on feedback from their Saturday professors. Their assigned readings discuss in greater detail the purposes of different types of evaluations and corresponding research designs. Most students have never had any experience designing a research project and need quite a bit of guidance and practice with decision making, for example, aligning evaluation purposes with evaluation types and matching research questions with appropriate collection tools. The following week is devoted to giving the research collaboratives time to flesh out Chapter 3 (Methodology) and assign sections to team members for more in depth writing. Readings deal with different types of sampling procedures and data collection tools, which we cover in greater detail the next week. We then hold conferences to refine data collection activities and corresponding sampling plans.

The final weeks of the semester focus heavily on refining writing and editing skills via intensive conferences and mentoring sessions during regular class time, in addition to scheduling supplemental sessions as needed. Collaboratives turn in their completed proposal at the end of the semester and have additional opportunities to revise their work based on faculty feedback. Thereafter, they present their proposal to their client to ensure that the client agrees to the plan and can confirm access to the necessary data points.

\footnotetext{
${ }^{1}$ We have developed teaching materials (e.g., logic model template, rubrics) to share with Journal of Research on Leadership Education (JRLE) readers. Please, contact Katherine if you are interested in obtaining these materials.
} 


\section{Part 2}

During the spring semester of Year 2, the cohort is enrolled in the second half of the methods course. They are also enrolled in a Saturday workshop that teaches students how to store, manage, and present data in a variety of meaningful ways. During the second semester, we continue with the format of holding 10 four-hr intensive class sessions that include hands-on learning and close mentoring. Most of the concepts and skills were introduced during the prior semester (e.g., how to ask good interview questions), while students actually develop interview questions and practice interview skills during Semester 2.

Session 1 opens with research collaboratives informally presenting to the whole group how their client meeting went during the winter interim and whether changes were requested and, if so, why. We discuss as a large group the importance of documenting any changes to the research plan and detailing reasons for this decision in the third chapter. This leads into our interactive lecture on the topics of feasibility, accuracy, validity, and credibility. We explain the importance of keeping a fieldwork data binder in which they can organize documents, interview notes, observation notes, surveys, test scores, and so on. (Some teams prefer developing online platforms to store data, while others choose to store data in literal binders.) After a break, we spend the next 2 hrs leading a session on conducting observations and taking field notes, offering a template for their consideration as well as time to practice this skill. Students share their notes with their group members to check where they diverge and coalesce.

During Session 2, we continue our discussion on observations and introduce formal observation instruments and how those differ from more open-ended field notes. We then present best practices for conducting interviews and focus groups and set up scenarios to give students practice in both.

We devote Session 3 to developing and administering surveys. We present best practices but provide numerous samples of "good" versus "bad" questioning techniques. We use two to three online tutorials that are a mix of guided practice and independent practice. ${ }^{2}$ The following week, groups develop their collection instruments with direction from their faculty mentors.

The fifth and sixth sessions focus on data analysis and interpretation procedures. This 4-hr session is very intensive, as we take them through hands-on activities using authentic field notes, interview transcripts, and survey data from prior studies conducted by faculty. Meanwhile, students are conducting their fieldwork and collecting data. They also begin their Saturday workshops around this time. While earlier classes with us utilized "canned" data for practice purposes, when they begin their Saturday classes, they use the data they have been collecting in the field to learn how to create data displays that are appropriate for a variety of data types.

The second half of the spring semester is designed to be more like working with a "chair" on a dissertation or capstone rather than a class, per se. Research collaboratives continue collecting data and are encouraged to complete fieldwork by early March. We meet with each of our groups individually for intensive one-on-one sessions that are tailored to the needs of that particular

\footnotetext{
${ }^{2}$ We have put together a list of websites and URL addresses so that readers might take advantage of some of the tools we found helpful. Please, contact Katherine if you are interested in obtaining this list.
} 
group. For example, while all students learned to use SPSS during Year 1, one group may need a refresher to move forward from data collection to data analysis and interpretation. Another group might share their coding scheme for focus group transcripts and talk through inter-rater reliability and thematic development with us. Thus, the number of meetings, how long they last, and where they take place vary from week to week.

The course culminates with presenting a final technical report (similar to the 5 chapters of the dissertation), executive summary (and other deliverables as requested by the client), and presentation to us and their peers. The larger group provides insights on how groups might strengthen the communication of their findings and recommendations. Then, collaboratives take their presentations, along with their final products, to the client as a culminating activity.

\section{What We Learned From Our Experiences}

Parallel to our literature section, our discoveries and insights fall into four major categories: (a) giving careful attention to andragogy versus pedagogy, (b) engaging the potency that team teaching affords, (c) addressing challenges associated with the practitioner-scholar model, and (d) building on the strengths of the cohort model. Earlier, we shared what we learned from existing research. In this section, we share what we learned from our on-the-ground realities and some of the strategies we employed in response. But first, we further explain our meaningmaking processes.

\section{Our Meaning-Making Processes}

To make meaning of our experiences, we used specific reflection processes and qualitative analysis strategies. For example, we each took field notes while engaging in participant observation while the other instructor took the lead with the students. We read our notes and examined them as a whole, together. Thereafter, we engaged in reflective dialogue, either immediately after class face-to-face or later by phone, asking questions such as the following:

1. Were students engaged? How do we know?

2. Did we power share? That is, were students active in the decision-making process during at least part of the class?

3. Did students raise any specific concerns? Did they express discomfort with any activity? If no verbal cues were present, did students use any physical signals to indicate negative feelings? If so, how and what?

4. Did students express any positive feelings or thoughts? Did they express enjoyment or thankfulness for any specific activity? If no verbal cues were present, did students use any physical signals to indicate positive feelings? If so, how and what?

5. Did we check for understanding? Did we have to do any re-teaching? (Or, will we need to do any re-teaching next week?)

6. What changes would we make if we were to do this again? What would we keep? What would we discard?

The month following the end of the semester, we studied our course evaluations to better understand our experiences and improve our practice. We began by looking at the data and 
comparing them with our written reflections collected over the course of the semester. We did this to gain a general understanding of how our initial impressions aligned (or not) with what students reported.

We then compiled descriptive statistics drawn from the survey questions that were answered with a Likert-type scale. In addition, we compiled all responses to open-ended questions and grouped them into themes. We also compared scores and comments with Katherine's past evaluations. We were curious to know whether there would be qualitative distinctions in terms of the nature of student comments. These data points are integrated within our reflective narrative.

\section{Andragogy Versus Pedagogy}

Before beginning our collaboration at the start of the fall semester, we discussed our teaching philosophies and discovered we both had a very strong commitment to a constructivist approach to teaching and learning, that is, the belief that student learning is an active process in which learners construct new ideas or concepts based on prior and emergent knowledge. In addition, we both embraced the philosophy of offering developmentally appropriate concepts and activities that provide suitable scaffolding for students so that they may grow from what they know to what they need to know. We also kept in mind Vygotsky's theory of learning, which posits that teachers are responsible for stimulating students to their zone of proximal development. That is, concepts and activities must not be so undemanding that students are bored or not pushed forward; nor, are they to be so difficult as to lead students to frustration overload and cause them to give up. Rather, being in the zone means activities are challenging and even uncomfortable, but are doable with the proper support from instructors.

Not only were we thankful to find we both were on the same page, so to speak, but we also communicated these concepts to our students on the first day of class. We have found that students need to hear up front that doctoral studies are often difficult and cause some amount of discomfort, but that this is a good thing. It means they are constructing new knowledge. We would even prime some of our lessons with an opening discussion reminding students of these concepts. In addition, we found students appreciated knowing why they were learning about sampling procedures, for example, as well as understanding what the intended outcome was. We found these simple strategies to be very effective to helping students be patient with themselves, with each other, and with us. Referring to cognitive theory helped students understand themselves as learners while also bolstering their trust in us as teachers, ultimately giving them the confidence they needed to move forward.

While the above foundation was essential to establish first, we also found we learned things in real time. We were sure to spend some time debriefing after class to establish what went well, what was less successful, and how we could make the following week even better. We consulted our notes and found additional tips to share that may not have been mentioned in the literature. For example, from the research, we learned that adults come ready to learn. What the literature did not engage was how tired students would be at the end of a long workday. Nor did researchers mention some of the strategies needed to combat this exhaustion and help students transition to a mind-set to be ready to engage in the learning process. It became clear early on that sessions needed to be engaging and audience appropriate. But, we also found that our 
students needed a transitional activity to help them unwind from a long day and be ready to switch gears. Thus, we recommend some sort of opening ritual as well as some time for students to interact with their peers and instructors prior to starting the lesson. What worked well for us was giving the research groups about $20 \mathrm{~min}$ at the beginning of class to discuss progress while we circulated the room and answered questions. We also found this a good time to hear about a student's particularly trying day and help them talk through their situation.

Student evaluations. We consulted student evaluations to help us better understand how students perceived the course and our facilitation of it. It was helpful that we had a $100 \%$ response rate for the 2015 course. We compiled all the student comments and grouped them thematically. All comments were positive and reflected an appreciation that the course was relevant and studentcentered and that we, as faculty, were accessible, were helpful, had high expectations, and practiced, "power with." The student comments clearly reflected an understanding of andragogy versus pedagogy, while they may not have used those exact words. (Please, see Appendix E, F, and $\mathrm{G}$ for survey questions and coding scheme.) For example, students remarked that course content was "directly useful" and related to "real work." The students also noticed that we purposefully shared power with them, "did not try to talk down to" them, and treated them as "real doctoral students," "professionals," and "collaborative peers." Comments also reflected an understanding of our constructivist approach to teaching:

Dr. Kat and Dr. Jaime facilitated discussion and helped us scaffold to higher level thinking without feeding us the answers. Their required work was meaningful and helped me grow as a researcher.

They know how to direct students when they need to be directed, and how to step back when they need to struggle and find answers on their own. All the while, they are unfailingly supportive, encouraging, and confident.

They encouraged us to dig deep and challenge ourselves, but they still kept us on track if we ventured out too far.

These student comments were confirmation to us that not only did we approach the course andragogically, rather than pedagogically, but that doing so resulted in the positive benefits we were hoping for. We felt a sense of confirmation when we examined the comments from prior iterations of the course. For example, in the prior cohort, students' feedback focused on two major themes: (a) appreciation for the guest speakers and (b) suggestions for how to handle snow days. There was very little additional commentary. (Please, see Appendix E, F, and G for survey questions and coding scheme.) It is important to note that only $46.7 \%$ of students responded to the course evaluation survey that year. Thus, these data cannot be construed as representative of the entire class. However, when compared with the class we co-taught, the number and nature of the comments differ greatly. First, $100 \%$ of students in the co-taught cohort participated in the survey and we were surprised to see that all comments were positive. ${ }^{3}$ And, as mentioned above, the majority of comments fell into four major themes: the relevance of the coursework, an appreciation for the way the course was student-centered, acknowledgment that the professors

\footnotetext{
${ }^{3}$ Not only were we shocked, we immediately recognized that this has never happened to us in the past and most likely would never happen again!
} 
were regularly accessible and helpful, and comments that supported our philosophy of "power with" rather than "power over." While we would never claim this data as hard evidence that we perfectly accomplished what we set out to do; overall, we feel comfortable sharing that we feel our experiences mirror the literature inasmuch as we can see: that students do, indeed, notice when and if instructors make courses andragogical rather than pedagogical. (Not to mention, this was Katherine's third time teaching this course and was committed to moving her practice to more andragogical foci.)

\section{Team Teaching}

We had known one another solely on a professional level before having the opportunity to teamteach, and that is sometimes more than other teams have before jumping into a collaborative teaching situation. We trusted one another as professionals, knowing each had the best interests of students in mind as class responsibilities were established. However, we were unsure of how our instructional methods would complement one another. We knew some amount of time would be required to ensure we worked as an effective team, but we had made a commitment to provide a rigorous and meaningful learning experience to cohort members.

Planning time was never easy to come by. The schedules of a practitioner and scholar are rarely compatible. To facilitate planning sessions, Katherine would often work around Jaime's school day schedule; meaning meetings often took place after conventional work hours. Both of us became proficient with the use of online collaboration platforms such as Google Docs and Dropbox to develop lesson plans, presentation slides, and course materials. All items could be edited in real time making after-hours and over-the-phone planning easier. As we got to know one another on a personal level, we also began to understand each other's instructional strengths. Katherine presented a strong perspective from a scholar's point of view, while Jaime took the practitioner's standpoint, providing students a variety of perspectives.

Working as an effective team also meant we were able to present as a unified front when addressing student issues. As stated before, students in a cohort have the potential to put their instructors at a disadvantage. When cohort members had a concern, we addressed any issues together, making sure any messages or responses given to students were uniform. This does not mean the instructional team never disagreed on issues pertaining to coursework. Rather, we discussed our concerns, weighed the issues, and came to a consensus before addressing any concerns alongside students.

Early on in the first semester of coursework, we quickly understood the importance of reflecting upon each session. If time could not be taken right after class ended, a phone call the next day was eminent. The reflective process was used to determine what components of the session went well, what required adjusting, and what future planning needed to look like. Course evaluation responses showed the effort made in establishing an effective teaching team paid off. Students expressed that they appreciated receiving abundant feedback and noted the perspectives of the two instructors enhanced the course experience. Cohort members also felt that we were "truly student-centered faculty members" who "tailored the course and presentations to the needs of all students in the course and did not teach to only one subset." (Please, refer to Appendix F). 


\section{The Practitioner-Scholar Model}

Working with such a diverse group of individuals can be enriching, as we can certainly learn from the experiences each participant brings to the program. However, working to educate a such diverse group also generated concern that instructional needs might not be met. For example, while one group of students may feel they are provided a well-equipped toolbox upon graduation, others may view that toolbox as rather sparse. Since students began coursework in the inaugural EdD cohort at VCU, the course sequence and content covered within each course has continued to evolve based on student and instructor feedback. For example, a greater emphasis has been placed on providing instruction on professional writing practices earlier in the course sequence by devoting the majority of the first semester to the scholarly writing process. While designing and refining the course sequence to best serve the multifaceted group of participants VCU's program now attracts, faculty also needed to ensure students were being provided with experiences which will enhance their capacity to grow as leaders and learners. Although the course structure has changed somewhat, themes including team-building, research literacy, reflective leadership, organizational context, and data management remain constant (Virginia Commonwealth University, n.d.).

With the ability to conduct meaningful and relevant research being such a critical component to the practitioner-scholar's repertoire, ensuring students had several opportunities to practice research literacy was important. Recall that one of the first team projects entailed student teams researching and presenting one of the four paradigms, or worldviews: postpositivist, pragmatic, constructivist, and transformative (Mertens \& Wilson, 2012). Although students were given detailed instructions, a rubric, and detailed text, they genuinely struggled with the assignment, and the presentations were not as strong as we expected them to be.

To ensure students had understanding of the research paradigms, we followed up with a largegroup re-teaching activity: an electronic Jeopardy! @ game. ${ }^{4}$ Later in the course, when research collaboratives had been established, we met with each team individually to discuss what paradigm might best fit the purposes of their project. Meanwhile, collaboratives met with their client to discuss their outline of the project and learn as much as they could about client needs.

Although students had prior exposure to research methods in previous coursework, fellow faculty indicated cohort members continued to struggle when it came time to test their skills during the capstone year. Thus, in addition to discussing a range of research methods at length, we also infused a variety of hands-on activities to ensure students became more comfortable with how all components of the methodology fit together. An example of this involves a large-group activity that has been very effective communicating these important concepts for developing the third section of the proposal (Methods). We give students plenty of guided practice as a large group using giant "Methods Matrix" posters that accommodate stick-on research questions and a plethora of collection tools that students match and display. ${ }^{5}$ Large-group discussion helps us tease out whether these evaluation designs are, indeed, aligned properly. We then move to small

\footnotetext{
${ }^{4}$ Please, contact Katherine if you are interested in obtaining this additional teaching tool.

${ }^{5}$ Please, contact Katherine if you would like to obtain a more in-depth description of this activity with accompanying tools.
} 


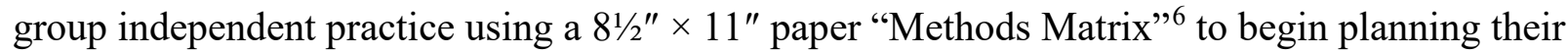
methods section of the proposal. Professor Mentors circulate throughout the room, working with small groups, to help refine research questions, sharpen their design rationale, and discuss what tools might work best to answer their research questions.

As research questions were developed and refined, it became apparent student teams would require individualized attention. While time had been taken during class sessions to review the variety of data collection tools students might apply to their research, there was not time for students to become completely immersed in the study of a single method, as they most likely would in a $\mathrm{PhD}$ program. To address this, students were provided with additional instructional support tailored to their needs. For example, teams who elected to administer a survey as a component of their research received additional instruction pertaining to surveys over and above what was covered in class. Supports were tailored to ensure students had a firm understanding of the method they were using, so the desired results were achieved.

Students were encouraged to share their "Findings/Results" section periodically to receive feedback and give them opportunities to edit their work. Much of their final section ("Conclusions and Recommendations") were developed verbally first during our mentoring sessions. We also read early versions of this section to provide feedback and give students ample opportunities to strengthen their final versions - another critical component to this process that would not have been possible without the relationships cohort members had developed with one another. While we conferenced with teams during work sessions, other students exchanged drafts of their final reports with their peers to garner additional feedback and reap opportunities to edit their work. Cohort members felt comfortable sharing their work because they had a firm understanding of the insight their teammates possessed at this point in the program. Also, they had been practicing the peer review process from the beginning of the program.

\section{The Cohort Model}

This particular cohort did not exhibit some of the negative characteristics the research points out. While this was Jaime's first time teaching the research classes, this was the third year that Katherine did so. Out of the three cohorts Katherine taught, one was particularly difficult. It became very clear early on that year that the cohort was not only very tight knit but also very distrustful and demanding of faculty, challenging every decision that was made, from grading procedures to the arrangement of student tables. Katherine used many of the same activities from the class under discussion with other cohorts, but this particular group was not as receptive as the others. For example, some would refuse to leave their seats to participate in large-group activities. Or, they would spend time on Facebook or texting during class.

Katherine responded by holding individual conferences with students before or after class and during the week, as well as consulting with more seasoned faculty for advice. Regardless of the nature and frequency of intervention strategies, it became clear that some students' attitudes and behaviors would not change. Tenured professors encouraged Katherine to maintain a positive attitude and persevere because "some students and cohorts are just like this." They also urged Katherine to not shy away from assigning the grades that students deserved. So she did. And a

\footnotetext{
${ }^{6}$ Please, contact Katherine if you would like a copy of this additional teaching tool.
} 
handful of students showed their displeasure in very tangible ways, for example, complaining to university administration. Thankfully, the upper administration and faculty review committees found Katherine's actions were appropriate and were in line with VCU's accountability standards. In addition, a few students privately thanked Katherine for holding everyone to high standards. They remarked that they had "worked so hard and did not think it was fair for those unwilling to work to "get a pass."

Thankfully, not all cohorts are this unwieldy. In fact, during the time that we have worked with the program, most students have been mature, respectful, and eager to learn. More often than not, it has appeared to us that going through the coursework together helps students build support systems that otherwise might not be possible. The collaborative nature of the program teaches students how to deal with difficult people and nurture close relationships. In addition, it must be noted that Katherine was alone teaching the more challenging group. We wonder whether having a teaching partner that year might have resulted in different outcomes. It is definitely worth discussing as a department. It may be that members of the more difficult group were acting out in response to Katherine's limited experience and/or lack of emphasis on concepts such as power with. Either way, Katherine reflected on her prior experiences and was committed to improving her practice. Sharing her prior experiences with Jaime enabled them to approach their team teaching experience with a more focused approach to building the positive aspects of the cohort model, such as modeling effective collaboration and handling differences of opinion and/or approach.

\section{Refining Our Practice and Making Program Adjustments}

Upon reflecting on the literature, student evaluations, and feedback gathered from faculty, it was clear that many of the changes we implemented during the 2014-2015 academic year, such as centering classroom practices andragogically and taking full advantage of the positive aspects of team teaching, we also reflected on the ways we could continue to refine our practice. For example, while all students had been introduced to, and practiced conducting, a wide array of qualitative and quantitative methods; students' levels of expertise varied greatly depending on the type of evaluation they chose to develop and implement. That is, a group conducting a research project involving interviews, focus groups, and a survey did, indeed, successfully complete their "practice capstone." But this particular group would not have gained additional preparation utilizing specific quantitative methods, such as conducting a cost-benefit analysis. Similarly, there were three groups who conducted quantitative studies, two of which employed a quasi-experimental design. Thus, while honing their skills collecting, manipulating, and reporting quantitative data during their practice capstone, these particular students did not gain additional experience practicing qualitative methods such as participant observation, interviews, and focus groups. (Please, refer to Appendices A and B for sample titles of studies.) Although this may not seem particularly alarming, as doctoral students almost always choose to do studies that require implementing methodologies and methods with which they are most familiar, it is important to recognize that students in that position are working on a traditional dissertation, not on a problem of practice designed to meet particular client needs, and usually take between 3 and 7 years to complete their $\mathrm{PhD}$ programs. The students in the $\mathrm{EdD}$ program are in a strict cohort model that is completed in exactly 3 years. Their ability to choose their own research study during their second year may not result in the opportunity to hone the specific skills necessary to 
fulfill client requests the following year. Therefore, capstone chairs sometimes have the added responsibility of doing some re-teaching, in addition to the usual chairship guidance, which can be time-consuming when compared with chairing a dissertation.

Table 1. Comparison of Content Covered in the Course.

\begin{tabular}{|c|c|c|}
\hline & 2014-2015 course topics & 2015-2016 course topics \\
\hline September & $\begin{array}{l}\text { Completion of CITI Training } \\
\text { Conflict of interest, ethics in research } \\
\text { Utility standards } \\
\text { Research paradigms (worldviews) }\end{array}$ & $\begin{array}{l}\text { Completion of CITI Training } \\
\text { Conflict of interest, ethics in research } \\
\text { Research paradigms (worldviews) } \\
\text { Quantitative research methods } \\
\text { Topic/problem selection }\end{array}$ \\
\hline October & $\begin{array}{l}\text { Formation of research teams } \\
\text { Logic model development } \\
\text { The Evaluand } \\
\text { Working with stakeholders } \\
\text { Aligning evaluation purpose, type, design, and } \\
\text { question development. } \\
\text { Study design (e.g., case study, ethnography, quasi- } \\
\text { experimental, concurrent/sequential mixed methods) }\end{array}$ & $\begin{array}{l}\text { Survey research, development, and analysis } \\
\text { Drafting and presentation of survey findings } \\
\text { Group critique of various survey studies }\end{array}$ \\
\hline November & $\begin{array}{l}\text { Validity and reliability } \\
\text { Credibility and dependability } \\
\text { Planning for data collection } \\
\text { Data collection options } \\
\text { Sampling methods } \\
\text { Matching methods to research questions } \\
\text { Development and approval of evaluation proposal }\end{array}$ & $\begin{array}{l}\text { Cost analysis research and design } \\
\text { Development and implementation of a cost } \\
\text { analysis } \\
\text { Drafting and presentation of cost analysis } \\
\text { findings } \\
\text { Group critique of various cost analysis studies }\end{array}$ \\
\hline Interim & $\begin{array}{l}\text { Delivery of an interim report to stakeholders } \\
\text { Collection and organization of field notes, } \\
\text { documents }\end{array}$ & Students receive a break at interim \\
\hline January & $\begin{array}{l}\text { Data management } \\
\text { Feasibility, accuracy } \\
\text { Observation instruments } \\
\text { Focus groups/interviews } \\
\text { Survey development and administration } \\
\end{array}$ & $\begin{array}{l}\text { Qualitative research methods and frameworks } \\
\text { Critique of qualitative research studies }\end{array}$ \\
\hline February & $\begin{array}{l}\text { Conduct fieldwork } \\
\text { Central tendency (mean, median, mode range, } \\
\text { standard deviation) } \\
\text { Using nominal, ordinal, interval data } \\
\text { Inductive vs. deductive reasoning } \\
\text { Data analysis vs. interpretation } \\
\text { Constructing emergent themes from qualitative data }\end{array}$ & $\begin{array}{l}\text { Purposeful sampling } \\
\text { Interviews/focus groups } \\
\text { Notetaking } \\
\text { Codes, categories, themes pertaining to } \\
\text { qualitative research }\end{array}$ \\
\hline March & $\begin{array}{l}\text { Continue fieldwork } \\
\text { Communicating and reporting findings } \\
\text { Drafting of findings and recommendations }\end{array}$ & $\begin{array}{l}\text { Qualitative writing structure (narrative, } \\
\text { phenomenology, grounded theory, case study) } \\
\text { Adding quotes in qualitative research }\end{array}$ \\
\hline April & $\begin{array}{l}\text { Finalization of full document } \\
\text { Development of executive summary } \\
\text { Presentation of findings to stakeholders }\end{array}$ & $\begin{array}{l}\text { Utilizing secondary data sets in qualitative } \\
\text { research } \\
\text { Descriptive statistics, tests of relationships, tests } \\
\text { of difference } \\
\text { Presentation of findings, drawing conclusions } \\
\text { based on utilization of secondary data sources. }\end{array}$ \\
\hline
\end{tabular}

Note. CITI = collaborative IRB training initiative; IRB = institutional review board.

This understanding brought faculty together to examine course components in light of these concerns. Given the course sequence for the EdD program had just been restructured 
(Appendices $\mathrm{C}$ and $\mathrm{D}$ ), the time to make adjustments in course content was ideal. The goal was to change aspects of Year 2 readings and activities which preserved a degree of student autonomy, while also bolstering students' capacity in both qualitative and quantitative research methods. The major change was reorganizing the "practice capstone" from a year-long program evaluation utilizing a very specific approach, such as a quasi-experimental design, into smaller "mini studies." That is, groups selected a topic that would be examined from at least three different vantage points. A great deal of time was taken in the first few classes to ensure selected topics were broad enough to allow for the wide variety of methods that were taught to be applied, including survey, focus group, interview, cost analysis, and utilization of secondary sources. The table below provides the reader with a comparison of session topics presented during the 20142015 and 2015-2016 academic years (Table 1).

While much of the content covered during the 2015-2016 academic year was similar to that of the 2014-2015 school year, the practice of specific methods was spaced out in a manner which allowed more time for participants to work with and digest what was being learned in smaller chunks. While the sense is that students will have a firmer grasp on a greater variety of collection tools, there is also a measure of concern that students may have difficulties producing a comprehensive capstone proposal to be defended separately to both the client and faculty. The power of last year was that students had already experienced "writing the first three chapters" and had publicly defended the proposals of their practice capstones. This same holds true for crafting the final two chapters and conducting the client and faculty final defenses. The ultimate impact of the curriculum modifications will not be known until the current cohort has progressed through the capstone process.

\section{Conclusion}

The purpose in crafting this article was to reflect on the challenges and benefits associated with preparing future practitioner-scholars to conduct research and evaluation. First and foremost, a positive mind-set was a critical component in working through this model. As this was a new endeavor for us, we were well aware challenges would lie ahead. Instead of viewing these challenges as obstacles, we embraced them as teachable moments both for us and the students we worked alongside. This frame of mind was also integral in being able to model our expectations. Students we worked with needed to see Katherine and Jaime working together as a cohesive unit toward common goals.

Although this article has shown challenges exist associated with using the practitioner-scholar model, we have also pointed out the rich possibilities. We believe much of our success was driven by the fact that our partnership was composed of a full-time practitioner and a full-time scholar. We were able to communicate to both sides of the aisle, so to speak, and garner credibility and buy in. We were also able to utilize our individual strengths in synergistic fashion that ultimately provided participants a more holistic perspective.

Another secret to our success, so to speak, comes from our commitment to engage in reflective practice. The literature and our experiences concur that garnering insights from our experiences is not as useful without systematic reflection. We found that most of our insights came from reading about and experiencing the first three themes: andragogy versus pedagogy, team 
teaching, and the scholar-practitioner model. We surmise that there are a few probable reasons for this. First, this particular cohort did not present some of the problems portrayed in the literature or reflect the past negative experiences vis-à-vis the cohort model; thus, we could focus our reflections on and adjustments to other important course components such as modeling and implementing a collaborative environment. Second, there was no mention of the cohort model on the course evaluations, either in the questions asked or in the open-ended responses. Perhaps this is because using cohorts is a programmatic component rather than a choice that students and instructors freely make. It may be helpful for our colleagues and us to include reflecting on the cohort structure as part of the course evaluation process. Third, based on some of the negative characteristics that can emerge using the cohort model, it may be useful to make these dynamics a purposeful part of reflection and discussion for both students and faculty during the first year of coursework. Similar to how students are taught to recognize their learning styles, and how to problem solve when collaborative teams run into difficulties, faculty might also help students recognize when individual personalities are jeopardizing the cohort's effective functioning as a whole.

We hope that, in addition to offering insights, our work may inspire others to expand their research agenda to include systematic investigations into the strategies that work well with teaching practitioners how to conduct educational research and evaluation. We, along with the educational leadership field, can certainly use additional wisdom focused on the four distinct areas we have highlighted: andragogy versus pedagogy, team teaching, the scholar-practitioner model, and the cohort structure to build theory and strengthen practice specific to educational organizations.

Declaration of Conflicting Interests. The author(s) declared no potential conflicts of interest with respect to the research, authorship, and/or publication of this article.

Funding. The author(s) received no financial support for the research, authorship, and/or publication of this article.

\section{References}

Amrein-Beardsley, A., Zambo, D., Moore, D. W., Buss, R. R., Perry, N. J., Painter, S. R., Puckett, K. S. (2012). Graduates respond to an innovative educational doctorate program. Journal of Research on Leadership Education, 7, 98-122.

Auerbach, S. (2011). "It's not just going to collect dust on a shelf": Faculty perceptions of the applied dissertation in the new California State University (CSU) Ed.D. programs: Leadership education from within a feminist ethos. Journal of Research on Leadership Education, 6, 59-82.

Bailey, S. (2014). Scholar-practitioner leadership: A conceptual foundation. International Journal of Progressive Education, 10(3), 47-59.

Barnett, B. G., Basom, M. R., Yerkes, D. M., Norris, C. J. (2000). Cohorts in educational leadership programs: Benefits, difficulties, and the potential for developing school leaders. Educational Administration Quarterly, 36, 255-282. 
Barnett, B. G., Muth, R. (2008). Using action-research strategies and cohort structures to ensure research competence for practitioner-scholar leaders. Journal of Research on Leadership Education, 3(1), 1-42.

Bates, S. P. (1997). Whatever happened to organizational anthropology? A review of the field of organizational ethnography and anthropological studies. Human Relations 50(9),11471175.

Bista, K., Cox, D. W. (2014). Cohort-based doctoral programs: What we have learned over the last 18 years. International Journal of Doctoral Studies, 9, 91-20.

Black, W. R., Murtadha, K. (2007). Toward a signature pedagogy in educational leadership preparation and program assessment. Journal of Research on Leadership Education, 2(1), $1-29$.

Bowers, A. J., Murakami-Ramalho, E. (2010). The research journal club: Pedagogy of research in the preparation of students in educational leadership. Journal of Research on Leadership Education, 5, 335-356.

Brown, K. M. (2004). Leadership for social justice and equity: Weaving a transformative framework and pedagogy. Educational Administration Quarterly, 40, 77-108.

Centre for the Enhancement of Learning and Teaching . (1998). Team teaching. Centre for the Enhancement of Learning and Teaching, City University of Hong Kong, Kowloon, Hong Kong SAR. Retrieved from http://teaching.polyu.edu.hk/datafiles/R27.html

Crotty, M. (1998). The foundations of social research: Meaning and perspective in the research process. Thousand Oaks, CA: SAGE.

Danielson, L. M. (2009, February). Fostering reflection. Educational Leadership, 66(5). Retrieved from http://www.ascd.org/publications/educationalleadership/feb09/vol66/num05/Fostering-Reflection.aspx

Dean, K. L., Fornaciari, C. J. (2014). The 21st-century syllabus: Tips for putting andragogy into practice. Journal of Management Education, 38, 724-732.

Eisen, M. J., Tisdell, E. J. (2003-2004). Team teaching: The learning side of the teachinglearning equation. Essays on Teaching Excellence Toward the Best in the Academy, 14(7). Available from www.podnetwork.org

Emerson, R. M., Fretz, R. I., Shaw, L. L. (1995). Writing ethnographic fieldnotes. Chicago, IL: University of Chicago Press.

Ferraro, J. M. (2000). Reflective practice and professional development (ERIC Identifier: ED449120). Washington, DC: Education Resources Information Center Clearinghouse on Teacher Education. Retrieved from http://www.vtaide.com/png/ERIC/ReflectivePractice.htm

Fornaciari, C. J., Dean, K. L. (2014). The 21st-century syllabus: From pedagogy to andragogy. Journal of Management Education, 38, 701-723. 
Forrest, S. P., Peterson, T. O. (2006). It's called andragogy. Academy of Management Learning \& Education, 5, 113-122.

Guba, E. G., Lincoln, Y. S. (1998). Competing paradigms in qualitative research. In Denzin, N. K., Lincoln, Y. S. (Eds.), The landscape of qualitative research (pp. 195-220). Thousand Oaks, CA: SAGE.

Hanusch, F., Obijiofor, L., Volcic, Z. (2009). Theoretical and practical issues in team-teaching a large undergraduate class. International Journal of Teaching and Learning in Higher Education, 21, 66-74.

Hebert, T. R. (2010). The scholar-practitioner concept and its implications for self-renewal: A doctoral student's perspective. Scholar-Practitioner Quarterly, 4(1), 33-41.

Leigh, J., Bailey, R. (2013). Reflection, reflective practice and embodied reflective practice. Body, Movement and Dance in Psychotherapy: An International Journal for Theory, Research and Practice, 8, 160-171. doi:10.1080/17432979.2013.797498

Merriem, S. B. (2001). Andragogy and self-directed learning: Pillars of adult learning theory. New Directions for Adult and Continuing Education, 89, 3-13.

Mertens, D. M., Wilson, A. T. (2012). Program evaluation theory and practice: A comprehensive guide. New York, NY: Guilford Press.

Patton, M. Q. (2002). Qualitative evaluation and research methods (3rd ed.). Newbury Park, CA: SAGE.

Pemberton, C., Akkary, R. (2010). A cohort, is a cohort, is a cohort . . . Or is it? Journal of Research on Leadership Education, 5, 179-208.

Pollio, D. E., Macgowan, M. J. (2010). The andragogy of evidence-based group work: An integrated educational model. Social Work With Groups, 33, 195-209.

Salipante, P., Aram, J. D. (2003). Managers as knowledge generators: The nature of practitionerscholar research in the nonprofit sector. Nonprofit Management \& Leadership, 14, 129150 .

Seed, A. H. (2008). Cohort building through experiential learning. Journal of Experiential Education, 31, 209-224.

Smith, N. (2012, October 30). Reflective practice in higher education instruction. The EvoLLLution. Retrieved from http://evolllution.com/opinions/reflective-practice-inhigher-education-instruction/

Stanford University . (2007, Fall). Team teaching: Benefits \& challenges. Speaking of Teaching Newsletter, 17(1). Retrieved from http://web.stanford.edu/dept/CTL/Newsletter/fac ta teams.pdf

Virginia Commonwealth University (n.d.). Ed.D. In leadership program sequence. Retrieved from http://www.soe.vcu.edu/files/2015/10/NEW EdD ProgramSequence_2014forward.pdf 
Vanderbilt . (n.d.). Team/collaborative teaching. The Center for Teaching, Vanderbilt University, Nashville, Tennessee. Retrieved from http://cft.vanderbilt.edu/guides-subpages/teamcollaborative-teaching/

Walker, D. W., Haley-Mize, S. (2012). Content analysis of PhD and EdD dissertations in special education. Teacher Education and Special Education, 35, 202-211. doi:10.1177/0888406411431168

Whitby, T. (2015, April 13). The importance of andragogy in education. My Island View: Educational, Disconnected Utterance (blog). Retrieved from https://tomwhitby.wordpress.com/2015/04/13/the-importance-of-andragogy-in-education/

Wolcott, H. F. (2008). Ethnography: A way of seeing (2nd ed.). New York, NY: Altamira Press.

\section{Appendix A}

Titles of "Practice" Capstone Projects Completed Year 2 (2014-2015)

- Using a Quasi-Experimental Design to Evaluate the Effects of the Pre-Kindergarten Program at Central Virginia Public Schools

- But Why Does It Work and Can It Be Replicated?: An Appreciative Inquiry of Goodland County's Alternative Education Program

- Can Guaranteed Admission Program Students Keep Up With Medical School Peers?: A Mixed-Methods Evaluation Comparing Faculty Perceptions to Student Outcomes

\section{Appendix B}

Titles of Final Capstone Projects Completed Year 3 (2015-2016)

- The Case of Algonquin High School: An Appreciative Inquiry of the Restorative Practices Discipline Program With Implications for School Division Replicability

- Achieving Financial Stability Through Regional Collaboratives: A Cross-Case Analysis of United Way Programs in Jacksonville, Houston, and San Francisco With Implications for Strategic Planning in Richmond, VA

- The Efficacy of Implementation and Perceived Instructional Value of the DreamBox Math Program in Coal County Elementary Schools

\section{Appendix C}

EdD in Leadership Program Sequence (Previous). ${ }^{7}$

\begin{tabular}{|c|l|l|l|}
\hline \multicolumn{1}{|c|}{ Summer } & \multicolumn{1}{c|}{ Fall } & \multicolumn{1}{c|}{ Spring } \\
\hline Year 1 & $\begin{array}{l}3 \mathrm{hr} \\
\text { EDLP 700: Effective Learning } \\
\text { Networks (3 credits) }\end{array}$ & $6 \mathrm{hr}$ & $6 \mathrm{hr}$ \\
\hline
\end{tabular}

\footnotetext{
${ }^{7}$ The class of 2016 was the last cohort to follow this sequence.
} 


\begin{tabular}{|c|c|c|c|}
\hline & $\begin{array}{l}\text { Themes: Metacognitive processes } \\
\text { Leadership }\end{array}$ & $\begin{array}{l}\text { EDLP 702: Understanding Self as } \\
\text { Leader: Theory and Data Analysis } \\
\text { ( } 2 \text { credits) } \\
\text { EDLP 703: Understanding Self as } \\
\text { Leader: Practical Applications (1 } \\
\text { credit, on campus) } \\
\text { EDLP 715: Principles for } \\
\text { Professional Writing I ( } 3 \text { credits) } \\
\text { Themes: } \\
\text { Leadership } \\
\text { Team-building } \\
\text { Research Literacy }\end{array}$ & $\begin{array}{l}\text { EDLP 704: Frameworks for } \\
\text { Decision making: Legal } \\
\text { Perspectives ( } 3 \text { credits) } \\
\text { EDLP 705: Frameworks for } \\
\text { Decision making: Ethical } \\
\text { Perspectives ( } 3 \text { credits) } \\
\text { Themes: } \\
\text { Theory and policy related to } \\
\text { decision making } \\
\text { Formative Assessment I }\end{array}$ \\
\hline Year 2 & $\begin{array}{l}6 \mathrm{hr} \\
\text { EDLP 708: Leadership Presence (3 } \\
\text { credits) } \\
\text { EDLP 709: Equity and Leadership } \\
\text { ( } 3 \text { credits) } \\
\text { Themes: Laboratory of Practice } \\
\text { application of learning summary } \\
\text { of results organizational context }\end{array}$ & $\begin{array}{l}6 \mathrm{hr} \\
\text { EDLP 711: Evidence-informed } \\
\text { Perspectives on Practice I ( } 3 \\
\text { credits) } \\
\text { EDLP 716: Principles for } \\
\text { Professional Writing II ( } 3 \text { credits) } \\
\text { Themes: } \\
\text { Developing a program review } \\
\text { format for writing final report, } \\
\text { executive summary }\end{array}$ & $\begin{array}{l}6 \mathrm{hr} \\
\text { EDLP 713: Evidence-informed } \\
\text { Perspectives on Practice II (3 } \\
\text { credits) } \\
\text { EDLP 712: Planning for } \\
\text { Sustainable Change I ( } 3 \text { credits) } \\
\text { Themes: Strategic planning } \\
\text { Continued study from Fall semester } \\
\text { Preparation for Capstone Work } \\
\text { Presentations of Problems by } \\
\text { clients } \\
\text { Rationale } \\
\text { Research Objectives } \\
\text { Formative Assessment II }\end{array}$ \\
\hline Year 3 & $\begin{array}{l}6 \mathrm{hr} \\
\text { EDLP 714: Planning for } \\
\text { Sustainable Change II ( } 3 \text { credits) } \\
\text { EDLP 790: Capstone Development } \\
\text { ( } 3 \text { credits) } \\
\text { Capstone Development } \\
\text { Background } \\
\text { Writing Response to RFA } \\
\text { Research design } \\
\text { Meetings with clients } \\
\text { Candidacy }\end{array}$ & $\begin{array}{l}6 \mathrm{hr} \\
\text { EDLP 798: Capstone Plan } \\
\text { Implementation (3 credits) } \\
\text { EDLP 717: Communicating Data } \\
\text { Results (3 Credits) } \\
\text { Capstone plan implementation } \\
\text { Finalizing design } \\
\text { Data collection } \\
\text { Data analysis } \\
\text { Data management, analysis, } \\
\text { portrayal }\end{array}$ & $\begin{array}{l}\text { EDLP 799: Capstone Completion } \\
\text { ( } 3 \text { credits }) \\
\text { Capstone completion } \\
\text { Data analysis } \\
\text { Portraying data results } \\
\text { Conclusions, recommendations for } \\
\text { implementation } \\
\text { Presentation and defense } \\
\text { Graduation }\end{array}$ \\
\hline
\end{tabular}

\section{Appendix D}

\section{EdD in Leadership Program Sequence (Current). ${ }^{8}$}

\begin{tabular}{|l|l|l|l|}
\hline & \multicolumn{1}{|c|}{ Summer } & \multicolumn{1}{|c|}{ Fall } & \multicolumn{1}{c|}{ Spring } \\
\hline Year 1 & 6 hr & 6 hr & 6hr \\
& EDLP 700: Effective Learning & EDLP 702: Understanding Self as & EDLP 704: Frameworks for \\
& Networks (3 credits) & Leader: Theory and Data Analysis & Decision making: Legal \\
& EDLP 715: Principles for & (2 credits) & Perspectives (3 credits) \\
& Professional Writing I (3 credits) & EDLP 703: Understanding Self as & EDLP 705: Frameworks for \\
& Themes: Metacognitive processes & Leader: Practical Applications (1 & Decision making: Ethical \\
& Leadership & credit, on campus) & Perspectives (3 credits) \\
& Research literacy & ELDP 708: Leadership Presence (3 & Themes: \\
& credits) & \\
\hline
\end{tabular}

${ }^{8}$ In use since the 2017 cohort began the program in 2014. Currently, three cohorts of students follow this sequence. 


\begin{tabular}{|c|c|c|c|}
\hline & & $\begin{array}{l}\text { Themes: } \\
\text { Leadership } \\
\text { Team-building } \\
\text { Organizational Context } \\
\end{array}$ & $\begin{array}{l}\text { Theory and policy related to } \\
\text { decision making } \\
\text { Formative Assessment I }\end{array}$ \\
\hline Year 2 & $\begin{array}{l}6 \mathrm{hr} \\
\text { EDLP 709: Equity and Leadership } \\
\text { ( } 3 \text { credits) } \\
\text { EDLP 712: Planning for } \\
\text { Sustainable Change I ( } 3 \text { credits) } \\
\text { Themes: } \\
\text { Laboratory of Practice } \\
\text { Application of learning } \\
\text { Summary of results } \\
\text { Change theory } \\
\text { Organizational context }\end{array}$ & $\begin{array}{l}\text { 6 hr } \\
\text { EDLP 711: Evidence-informed } \\
\text { Perspectives on Practice I (3 } \\
\text { credits) } \\
\text { EDLP 716: Principles for } \\
\text { Professional Writing II (3 credits) } \\
\text { Themes: } \\
\text { Orientation to research, program } \\
\text { evaluation, and qualitative } \\
\text { analysis } \\
\text { Selection of and immersion in local } \\
\text { laboratory of practice } \\
\text { Renewed focus on writing in a } \\
\text { range of genres pertaining to } \\
\text { practice, particularly related to } \\
\text { interim and final reports to } \\
\text { evaluation clients }\end{array}$ & $\begin{array}{l}6 \text { hr } \\
\text { EDLP 713: Evidence-informed } \\
\text { Perspectives on Practice II (3 } \\
\text { credits) } \\
\text { EDLP 717: Communicating } \\
\text { Research Findings (3 credits) } \\
\text { Themes: } \\
\text { Facilitating closure of evaluation } \\
\text { research and local laboratory of } \\
\text { practice } \\
\text { Data management and effective } \\
\text { communication of research } \\
\text { findings } \\
\text { Formative Assessment II }\end{array}$ \\
\hline Year 3 & $\begin{array}{l}6 \text { hr } \\
\text { EDLP 714: Planning for } \\
\text { Sustainable Change II (3 credits) } \\
\text { EDLP 790: Capstone Development } \\
\text { ( } 3 \text { credits) } \\
\text { Themes: } \\
\text { Application of change theory to } \\
\text { problems of practice } \\
\text { Capstone Development } \\
\text { Background } \\
\text { Writing Response to RFA } \\
\text { Research design } \\
\text { Meetings with clients } \\
\text { Candidacy }\end{array}$ & $\begin{array}{l}3 \text { hr } \\
\text { EDLP 798: Capstone Plan } \\
\text { Implementation (3 credits) } \\
\text { Capstone plan implementation } \\
\text { Finalizing design } \\
\text { Data collection } \\
\text { Data analysis } \\
\text { Data management, analysis, } \\
\text { portrayal }\end{array}$ & $\begin{array}{l}3 \mathrm{hr} \\
\text { EDLP 799: Capstone Completion } \\
(3 \text { credits }) \\
\text { Capstone completion } \\
\text { Data analysis } \\
\text { Portraying data results } \\
\text { Conclusions, recommendations for } \\
\text { implementation } \\
\text { Presentation and defense } \\
\text { Graduation }\end{array}$ \\
\hline
\end{tabular}

\section{Appendix E}

\section{Course Evaluation Questions}

1. The instructor was well prepared for this course.

2. The instructor was available outside of the classroom (consider the instructor's availability during established office hours, appointments, and other opportunities such as voicemail and email, etc.) for additional consultation. If not applicable, leave blank.

3. The instructor graded and returned students' written work (exams, papers, and other assignments) in a timely manner.

4. The instructor presented course material in an organized and informative manner.

5. The instructor's choice of instructional materials facilitated my learning in this course.

6. The instructor's teaching techniques (discussions, lectures, group exercises, and other techniques used in the course) helped me lean the material in the course.

7. The instructor encouraged discussion, participation, and questions in the course 
8. The instructor treated students with courtesy and respect

9. The instructor clearly presented evaluative criteria for assessing my work

10. This course helped me understand what will be expected of me as a professional.

11. As a result of this course, my knowledge and skills were increased in the subject matter.

Scale

$5=$ Strongly agree

$4=$ Agree

$3=$ Neither agree or disagree

$2=$ Disagree

$1=$ Strongly Disagree

Free Response

1. What aspects of this course did you find most helpful or useful?

2. What do you believe the instructor did particularly well?

3. What suggestions do you have for the future, either in terms of content or possible ways to improve the course?

\section{Appendix F}

Coding of All Evaluation Comments (2015)

$100 \%$ Response Rate.

\begin{tabular}{|l|l|}
\hline Theme & \multicolumn{1}{|c|}{ Keywords from direct quotes } \\
\hline Relevant & Interesting and useful \\
Directly applicable \\
Meaningful and relevant \\
All of the content was directly useful \\
I finally felt like I was doing something productive and not just busy work \\
Activities related to real work \\
Required work was meaningful \\
Facilitate discussion \\
& $\begin{array}{l}\text { Did not add in busy work } \\
\text { Never wasted time inside or outside of class } \\
\text { Saved time and made everything more efficient } \\
\text { Very tactical } \\
\text { Purposeful guidance } \\
\text { Provided timely and useful feedback with suggestions for improvement }\end{array}$ \\
\hline Student centered & $\begin{array}{l}\text { Tailored course to needs of students } \\
\text { Flexible and reasonable } \\
\text { Appreciated student-centered approach } \\
\text { Is truly a student-centered faculty member } \\
\text { She truly understands the needs of graduate students } \\
\text { She was flexible and reasonable } \\
\text { Excellent at breaking down complex concepts into understandable language } \\
\text { Really made an effort to make sure we understood } \\
\text { Provided immediate, constructive feedback }\end{array}$ \\
\hline
\end{tabular}




\begin{tabular}{|l|l|}
\hline Accessible and helpful & $\begin{array}{l}\text { Always willing to meet outside of class } \\
\text { Individual meetings most valuable } \\
\text { Listened to our concerns } \\
\text { Good communication } \\
\text { Provided constructive feedback } \\
\text { Provided timely and useful feedback with suggestions for improvement } \\
\text { Terrific at responding quickly to emails or other communications } \\
\text { She gave thoughtful, constructive feedback } \\
\text { Feedback is very timely } \\
\text { Supportive and encouraging } \\
\text { She is very supportive } \\
\text { Unfailingly supportive and encouraging }\end{array}$ \\
\hline Power with & $\begin{array}{l}\text { Offered suggestions } \\
\text { Treated as professionals } \\
\text { Treated as collaborative peers } \\
\text { Worked with not for instructor } \\
\text { Helped us see, accept, and embrace transition from coursework to independent research } \\
\text { She treated us like doctoral students } \\
\text { She did not try to talk down to us I felt I was truly a doctoral student }\end{array}$ \\
\hline
\end{tabular}

\section{Appendix G}

Coding of All Evaluation Comments (2014)

46.7\% Response Rate.

\begin{tabular}{|l|l|}
\hline Theme & \multicolumn{1}{c|}{ Keywords from direct quotes } \\
\hline High expectations & $\begin{array}{l}\text { Made sure we understood expectations } \\
\text { She maintained high expectations for the end result } \\
\text { She encouraged us to dig deep and challenge ourselves } \\
\text { Directs students when they need it and steps back when students need to struggle and find } \\
\text { answers on their own } \\
\text { She turned us loose when she knew we were ready } \\
\text { Helped us scaffold to higher level thinking without feeding us the answers }\end{array}$ \\
\hline Research preparation & $\begin{array}{l}\text { Have never engaged with research at this level before and now feel prepared } \\
\text { Required work helped me grow as a researcher } \\
\text { Helped us increase our capacities to become better researchers } \\
\text { When doing research, you can teach the overall concepts and definitions, but application can } \\
\text { be challenging . . individual teaching was valuable } \\
\text { Gave us thoughtful, constructive feedback to strengthen our project }\end{array}$ \\
\hline other & $\begin{array}{l}\text { I respect her } \\
\text { I trust her }\end{array}$ \\
\hline
\end{tabular}

\section{Author Biographies}

Katherine Cumings Mansfield, $\mathrm{PhD}$, University of Texas at Austin, is an assistant professor at Virginia Commonwealth University where she teaches an array of courses such as Program Evaluation Theory and Methods, Critical Policy Analysis, Education Finance Policy and the Equitable Distribution of Resources, School-Community Relations, and Leadership for Social Justice and Equity. She has published in a variety of journals, including Educational Administration Quarterly, Educational Policy Analysis Archives, International Journal of Qualitative Studies in Education, and Journal of Research on Leadership Education. 
Jaime Stacy, EdD, Virginia Commonwealth University, possesses over 15 years of teaching and administrative experience in the field of education and currently serves as an associate principal for Henrico County Public Schools, Virginia. She has published in Planning and Changing Journal and Music K-8 Magazine and is a part-time faculty member for the School of Education at VCU. 